\title{
Flexible Electrochromic Windows: A Comparison Using Liquid and
}

\section{Solid Electrolytes}

\author{
Emerson Marcelo Girotto, and Marco-A. De Paoli*
}

Laboratório de Polímeros Condutores e Reciclagem, Instituto de Química, Unicamp,C.P. 6154, 13083-970 Campinas - SP, Brazil

\begin{abstract}
Neste trabalho foram montados e caracterizados dois dispositivos eletrocrômicos (ou janelas eletrocrômicas) utilizando como materiais opticamente ativos polímeros instrinsecamente condutores. Os materiais usados na montagem foram os mesmos, exceto pelo eletrólito usado. No primeiro foi usado como eletrólito uma solução de carbonato de propileno e no segundo o elastômero poli(epicloridrina-co-oxido de etileno), ambos contendo $\mathrm{LiClO}_{4}$. A condutividade elétrica do eletrólito líquido é aproximadamente duas ordens de grandeza maior $\left(10^{-3} \mathrm{~S} \mathrm{~cm}^{-1}\right)$ do que a do eletrólito sólido e foram obtidos excelentes resultados do ponto de vista eletrocrômico em ambos os casos. A eficiência eletrocrômica em $640 \mathrm{~nm}$ foi calculada em $700 \mathrm{C} \mathrm{cm}^{-2}$ para o dispositivo com eletrólito liquido e $360 \mathrm{C} \mathrm{cm}^{-2}$ para o dispositivo montado com eletrólito sólido. O uso de dispositivos eletrocrômicos de estado sólido tem chamado bastante atenção e suas vantagens são discutidas.

In the present work, two electrochromic devices (or electrochromic windows) based on intrinsically conducting polymers were assembled and characterized. For both devices, the materials used on the assembling were the same except for the electrolyte layer. In the first, we used as electrolyte a propylene carbonate solution and in the second the elastomer poly(epichlorohydrin-co-ethylene oxide), both containing $\mathrm{LiClO}_{4}$. The conductivity of the liquid electrolyte $\left(10^{-3} \mathrm{~S} \mathrm{~cm}^{-1}\right)$ is approximately two orders of magnitude higher than for the solid electrolyte and we obtained very good electrochromic properties in both cases. The calculated electrochromic efficiency at $640 \mathrm{~nm}$ was $700 \mathrm{C} \mathrm{cm}^{-2}$ for the liquid electrolyte device and $360 \mathrm{C} \mathrm{cm}^{-2}$ for the solid state device. Solid state electrochromic windows have been investigated and some of its advantages over windows with liquid electrolytes are discussed.
\end{abstract}

Keywords: electrochromic window, polymeric electrolyte, conducting polymer

\section{Introduction}

Recent publications of books ${ }^{1}$ and reviews ${ }^{2}$ on electrochromism and electrochromic devices demonstrate the interest in this area of research. In a recent paper $^{3}$ we used a dianionic dye to enhance the optical contrast of polypyrrole. Not only the use of dyes ${ }^{4}$, but other aspects are important: sol-gel deposition film methods ${ }^{5}$, temperature of deposition $^{6}$, counterion color influence ${ }^{7}$, oxygen flow during sputtered films ${ }^{8}$, coating the electrochrome with thin gold or platinum layer ${ }^{9}$, etc.

Nowadays the progress in science and technology points to new systems for energy storage or optics based on all polymeric (due to its lower costs) and flexible (due to its easy handling) devices, the so-called "cheap and bendy" devices ${ }^{10}$. Undoubtedly, the electrolyte plays an important role in the development of this technology. Polymeric solid electrolytes can be used without loss of the electrochromic parameters since the interaction polymer-electrolytecounter electrode is satisfactory. These desirable conditions could be reached studying new electrode-electrolyte preparation methods and perhaps a simultaneous film-electrolyte preparation.

The main functional features of commercial electrochromic devices for architecture and automotive applications are the reduction of light and heat transfer for thermal well-being and daylight control or glitter reduction for thermal and visual comfort. According to Monk and cols. ${ }^{1}$, electrochromic systems are divided as follow: (i) those constructed with electrochromes always in solution, (ii) with colorless electrochromes initially in solution and becoming a colored solid after electron transfer and (iii) with electrochromes as solid films on transparent electrodes. Indeed, the third type presents several advantages over the

e-mail: mdepaoli@iqm.unicamp.br 
others when using solid electrolyte, mostly related to prevention of leaking, sealing and solvent evaporation. Several works have focused on the use of polymeric electrolytes in electrochromic devices ${ }^{11-18,27}$ and, more recently, these have also been used for all plastic and flexible devices ${ }^{17}$. Notwithstanding these disadvantages, electrochromic devices assembled in liquid configurations (liquid, gel or highly plasticized polymer electrolyte) have demonstrated good optical contrast, stability and response time ${ }^{18}$. Often dimethylformamide or propylene carbonate (PC) solutions containing $\mathrm{LiClO}_{4}$ are used as electrolytes. For layered systems there are interfaces that significantly influence the kinetics assigned to mass and charge transport. A system that could facilitate these transports will present satisfactory results using the appropriate layer components. The rate limiting process usually encountered in type (iii) systems is ionic charge transport through the solid electrochrome as well as the diffusing species that enters the electrochrome via the electrolyte $\mid$ film interface.

In this work we describe the results of two electrochromic devices assembled in the same configuration except for the electrolyte used: propylene carbonate (liquid) or the elastomer poly(epichlorohydrin-co-ethylene oxide), $\mathrm{P}(\mathrm{EPI}-\mathrm{EO})$ (solid), both containing $\mathrm{LiClO}_{4}$. The cathodic electrochrome used was poly(3,4-ethylene dioxythiophene)-poly(styrene sulphonate) (PEDT-PSS, Bayer) and the anodic was polypyrrole-dodecylsulfate-indigo carmine (PPy-DS-IC) ${ }^{3}$. PEDT is used as anti-static coating for plastics, especially photographic films. Recently, its applications have been extended to solid electrolyte development for capacitors, through-hole plating of printed circuit boards $^{19}$, biosensors ${ }^{20}$ and photoelectrochemical cells ${ }^{21,22}$.

\section{Experimental}

The electrochromes were initially studied in situ as single electrodes in an electrolytic cell having platinum as counter electrode, $\mathrm{Ag} \mid \mathrm{AgCl}$ reference electrode and a propylene carbonate solution of $\mathrm{LiClO}_{4}\left(1.0 \mathrm{~mol} \mathrm{~L}^{-1}\right)$ as electrolyte. This was done to balance the charge regarding the opposite electrochromes. The redox charge was measured by chronoamperommetry and controlled by the synthesis charge. In a recent work ${ }^{3}$ we have described in details the method of synthesis and electrochromic characterization of PPy-DS-IC. As transparent electrodes, we used ITO-PET (poly(ethylene terphthalate) coated with indium doped tin oxide (I.S.T. Co., Belgium, $60 \Omega \mathrm{cm}^{-2}, 175 \mu \mathrm{m}$ thickness). The cathodic electrochrome was characterized in the same way but it was prepared by casting its diluted commercial solution (Baytron-P®, Bayer) on ITO-PET electrodes. The solid electrolyte was prepared by dissolving $0.60 \mathrm{~g} \mathrm{P}(\mathrm{EPI}-$ EO) (Daiso Co. Ltd.) and $0.032 \mathrm{~g}$ of $\mathrm{LiClO}_{4}$ (Aldrich) in $10 \mathrm{~mL}$ of tetrahydrofuran (Merck). These quantities give $n=29$, where $n$ is the ratio between the number of moles of oxygen atoms in the copolymer chain and the number of moles of metallic cation, $n=[\mathrm{O}] /[\mathrm{Li}]$. This solution was deposited on the modified electrodes and the solvent was evaporated until a plastic-like film was formed. The electrodes were carefully pressed until the polymeric electrolyte fixed them. Traces of THF were not completely removed. The solid electrolyte thickness was controlled with an adhesive tape spacer ( $35 \mu \mathrm{m}$ thickness) and the active area was $1.0 \mathrm{~cm}^{2}$ for both devices. The liquid electrolyte was a $1.0 \mathrm{~mol} \mathrm{~L}^{-1}$ solution of $\mathrm{LiClO}_{4}$ (Aldrich) in propylene carbonate (Riedel-de-Haën). This solution was deposited on the electrodes and the cells were assembled as described above maintaining the same distance between electrodes. The devices were assembled under atmospheric conditions. The measurements were carried out by placing the devices in the sample compartment of a spectrophotometer (Hewlett-Packard, 8452A) and switching the applied potential using a PG-05 Omnimetra potentiostat/galvanostat interfaced to a computer. For electrochromic device investigations, a simple two-electrode system was constructed in a sandwich configuration. Impedance measurements were performed using an EchoChemie Autolab PGSTAT10 potentiostat with a frequency response analyzer module. Sinusoidal perturbations of $\pm 0.010 \mathrm{~V}$ were applied between $0.1 \mathrm{~Hz}$ and $10 \mathrm{kHz}$ with polarized conditions $(-1.5$ to $+1.5 \mathrm{~V}$ with intervals of $0.5 \mathrm{~V})$. The ambient temperature and relative humidity were controlled and maintained at $20 \pm 1{ }^{\circ} \mathrm{C}$ and $\mathrm{ca} .45 \%$, respectively.

\section{Results and Discussion}

The interest in electrochromic devices based on conducting polymers is due to their good optical contrast and memory, stability and operation in a large range of temperatures. Although the first reports on electrochromes suggested no dependence on the angle of vision ${ }^{23}$, Nijnatten and Spee $^{24}$ have recently demonstrated the effect of the incident irradiation angle on a $12 \mathrm{~cm}^{2}$ electrochromic device. Among the electrochromic parameters, such as electrochromic efficiency (or coloration efficiency), $\eta$, stability (or cycle life), and optical contrast (or write-erase efficiency), $\Delta \% \mathrm{~T}$, only the optical memory and response time, $\tau$, are related to the kinetic phenomenon of bleaching and coloring. After almost two decades of research, the first pilot plants for the fabrication of large area devices are starting to operate ${ }^{25}$. However, these prototypes use liquid or highly plasticized polymers as electrolytes. Some electrochromic devices have been assembled and studied in our group $^{18,26-28}$, including small-scale prototypes. Traditional techniques such as cyclic voltammetry and chronoamperommetry, all associated with in situ spectroscopy measurements are employed for their characterization. It is not possible to construct a device using a reproducible refer- 
ence electrode. Thus, one of the electrochrome modified electrodes is used as reference. Hence, the potentials described in this work are relative to a PEDT-PSS electrode that was circuited as the counter-electrode.

After assembling, the devices were submitted to large potential range cyclic voltammetry $(-2.5$ to $4.0 \mathrm{~V})$ simultaneous to measurement of the transmittance at $640 \mathrm{~nm}$, in order to verify the minimum cathodic and anodic potentials required to guarantee a reasonable chromatic contrast value (Fig. 1). Clearly, the potentials of -1.5 and $1.5 \mathrm{~V}$ are optimal values to assure a $\Delta \% \mathrm{~T}_{640 \mathrm{~nm}}$ of $41 \%$ (liquid electrolyte) and $31 \%$ (dry polymeric electrolyte).

The stability was tested by performing 500 square wave double potential steps at -1.5 and $1.5 \mathrm{~V}$ with $15 \mathrm{~s}$ each of polarization (Fig. 2). This chronoamperometric experiment permits us to evaluate the cycle life, calculate the coloration efficiency, response time, and write-erase efficiency, Table 1 .

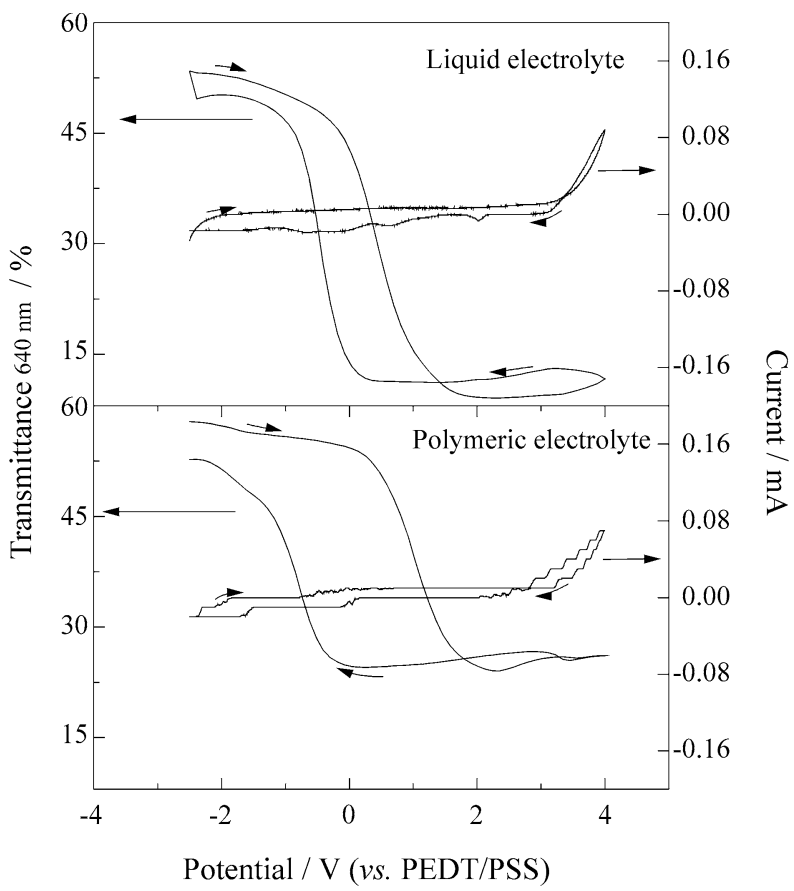

Figure 1. Transmittance variation at $640 \mathrm{~nm}$ measured during a cyclic voltammetry (-2.5 to $4.0 \mathrm{~V} v s$. PPI-DS-IC) for liquid and polymeric electrolyte devices.
We noted a progressive fall in the electrochromic properties as a function of the number of potential steps. The previous characterizations of PEDT-PSS and PPy-DS-IC as single electrodes have showed good electrochromic properties and stability. However, the films of PPy-DS-IC used in the device were deposited with smaller thickness to achieve a charge capacity equal to PEDT-PSS. This may increase the mechanical stress caused by the redox process

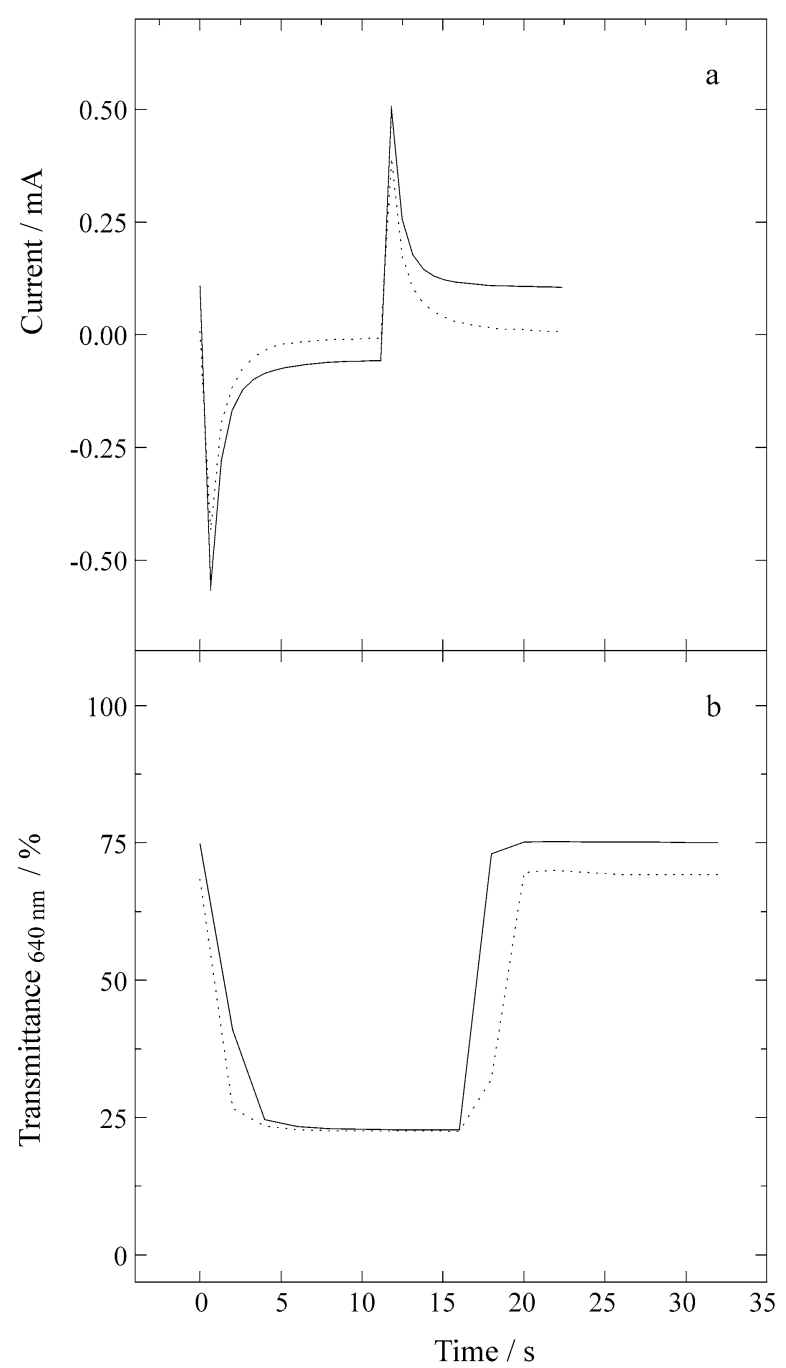

Figure 2. a) Double potential step and b) Optical contrast $(640 \mathrm{~nm})$ during $15 \mathrm{~s}$ of polarization at -1.5 and $+1.5 \mathrm{~V}$ using liquid electrolyte (dotted line) or polymeric electrolyte (full line) devices.

Table 1. Calculated electrochromic parameters for liquid (liq) and polymeric (pol) electrolyte devices.

\begin{tabular}{llcccccccc}
\hline$\eta_{\mathrm{b}}[\mathrm{a}]\left[\mathrm{cm}^{2} \mathrm{C}^{-1}\right]$ & & \multicolumn{2}{c}{$\eta_{\mathrm{c}}[\mathrm{b}]\left[\mathrm{cm}^{2} \mathrm{C}^{-1}\right]$} & \multicolumn{2}{c}{$\tau_{\mathrm{b}}[\mathrm{c}][\mathrm{s}]$} & \multicolumn{2}{c}{$\tau_{\mathrm{c}}[\mathrm{d}][\mathrm{s}]$} & \multicolumn{2}{c}{$\Delta \% \mathrm{~T}_{640 \mathrm{~nm}}[\mathrm{e}][\%]$} \\
\hline liq & pol & Liq & pol & liq & pol & liq & pol & liq & pol \\
714 & 404 & 747 & 319 & 7 & 9 & 4 & 4 & 47 & 52 \\
\hline
\end{tabular}

[a] Electrochromic efficiency for bleaching process. [b] Electrochromic efficiency for coloring process. [c] Optical response time for bleaching process. [d] Optical response time for coloring process. [e] Transmittance variation. 
of insertion/expulsion of ions. Besides, for electrochromic applications the humidity conditions are not so critical as when working with lithium based battery systems, so we did not work under strictly anhydrous conditions. The water present in the electrolytes could have reacted under polarization producing $\mathrm{O}_{2}$ and $\mathrm{H}_{2}$, leading to degradation of PPy-DS-IC (reaction with $\mathrm{O}_{2}$ ), and the formation of bubbles, decreasing the electrolyte-film contact. The relation between absorption change and the injected charge per unit area gives $\eta$. The value obtained in this work is notably higher than some values found in the literature for inorganic or organic electrochromes and devices ${ }^{1,14}$. This is caused by the high optical contrast of the device (Fig. 2b) and the low charge required to promote the optical change. In general, organic electrochromes exhibit a greater $\eta$ value than inorganic species because the molar absorptivities of the former are usually higher ${ }^{2}$. Figure $2 b$ apparently shows a disagreement with Fig. 1, where we can see the higher $\Delta \% \mathrm{~T}$ for the last. The difference is that in the experiment of Fig. 1, the chromatic contrast at $640 \mathrm{~nm}$ was registered during cyclic voltammetry and in the experiment of Fig. 2b the spectra were registered during a constant polarization of ca.1 min (-1.5 and/or $1.5 \mathrm{~V})$. This corresponds to the measurement of the response time of the devices.

Figure 3 shows the spectra of the bleached and colored form of the two devices. The write-erase efficiency for the device assembled with the polymer electrolyte is remarkable in comparison to the liquid.

As described above, the only difference between the devices is the electrolyte layer; one is an elastomeric polymer and the other a liquid solution, but both have the same thickness and contain $\mathrm{LiClO}_{4}$. Hence, we could assign the different behavior to the electrolyte layer. Resuming, it is clear that the device assembled with the polymeric electrolyte shows a shorter response time and, moreover, it is more sensitive at the potential of $-1.5 \mathrm{~V}$, i.e., in the bleached form. During the coloring and bleaching steps the current decays to zero for the device with the liquid electrolyte but not for the device with the polymeric electrolyte (Fig. 2a). Further, during the coloring step of the device with the polymeric electrolyte, the current decays to zero at the same rate for the bleaching step, but the transmittance reaches a constant value faster than during the bleaching process. This indicates that the kinetics of PPy-DS-IC oxidation/PEDTPSS reduction is faster than that of the reverse process, path two in Fig. 4.

The color persistence in the electrochromic devices is an important feature since it is directly related to aspects involved in its utilization and energy consumption during use. For electrochromic applications, electrochromic devices with good optical memories are necessary, avoiding a re-polarization of the electrochromes for the desirable color constancy. The color stability for the bleached and

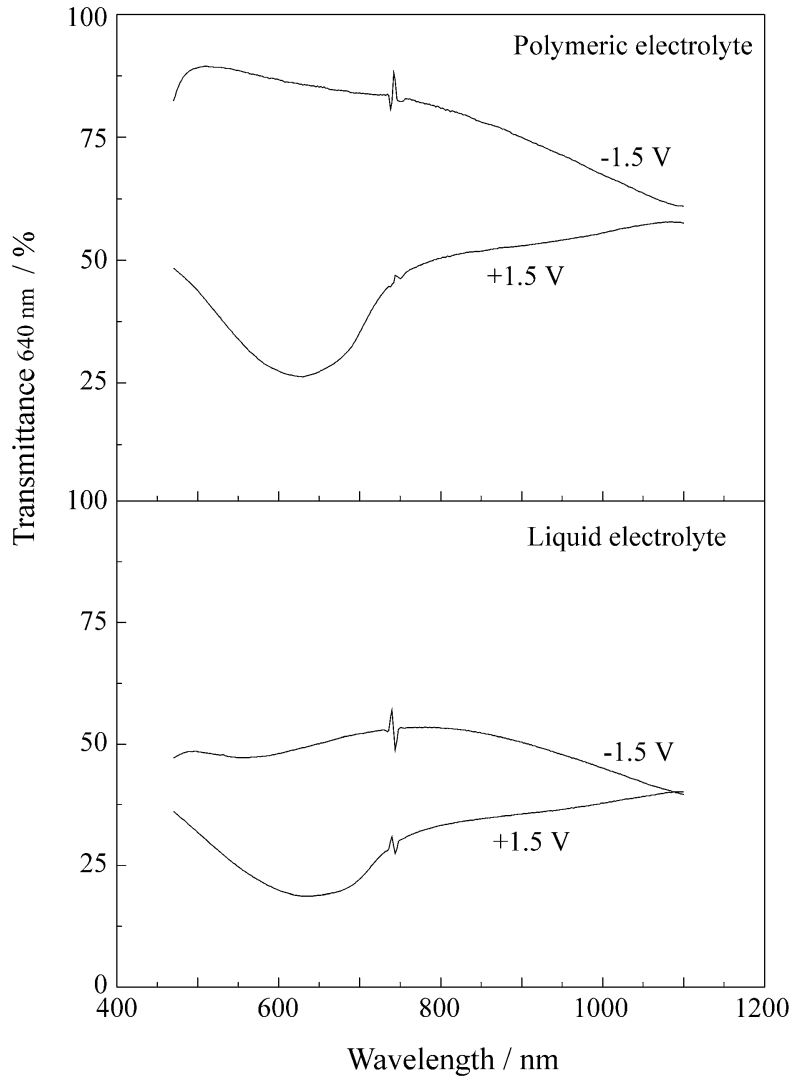

Figure 3. Transmittance spectra for bleached $(-1.5 \mathrm{~V})$ and colored form $(+1.5 \mathrm{~V})$ of the devices.

colored states of the electrochromic devices were investigated just after polarizations (-1.5 and $1.5 \mathrm{~V})$ at open circuit during $3.5 \mathrm{~h}$ (Fig. 5). For the device with polymeric electrolyte polarized in the bleached state, $\% \mathrm{~T}_{640}=80 \%$. After $1 \mathrm{~h}$ under an open circuit the $\% \mathrm{~T}_{640}$ changes to $65 \%$ and remains constant. When polarized in the colored state the device presents $\% \mathrm{~T}_{640 \mathrm{~nm}}=28 \%$, while after $1 \mathrm{~h}$ under an open circuit the $\% \mathrm{~T}_{640}$ changes to $40 \%$ and remains constant. These results indicate that this system does not reach equilibrium under open circuit conditions and presents a reasonable optical memory.

Electrochemical impedance spectroscopy measurements were carried out to determine the resistance of the electrolyte and to investigate its effect on the electrochromic properties of the devices, mainly on the response time. Nyquist plots for the devices (Fig. 6) were analyzed on the basis of a modified Randles circuit and using a fitting software $^{29}$. In Fig. 6 the points marked (x) represent the semi-circle fitting done by the software using an equivalent circuit. The resistance imposed by the electrolyte could be estimated by the first intersection of the curve with the real $(\mathrm{Z})$ axis, $\mathrm{R}_{\mathrm{e}}$. However, it does not give the real value of the electrolyte resistance, because the electrochromic electrodes are not blocking, thus, $\mathrm{R}_{\mathrm{e}}$ is the sum of the resistance of the electrolyte + PET-ITO + electrochromes. 


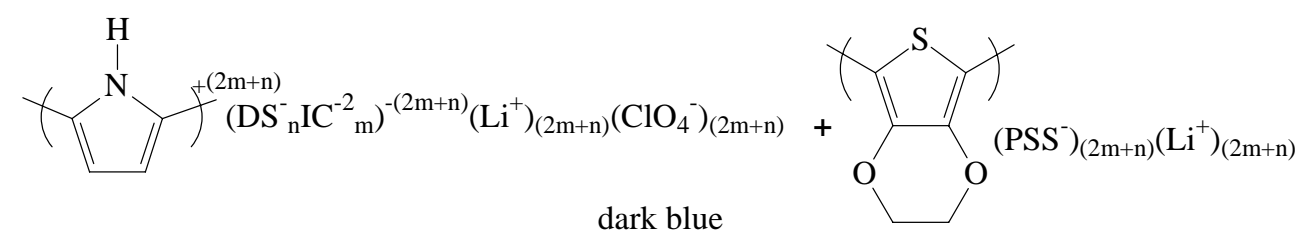

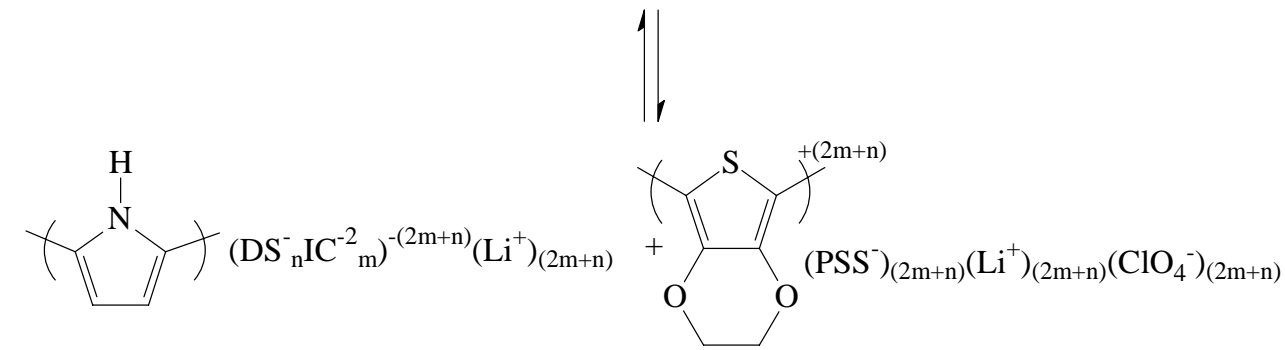
transparent pale yellow

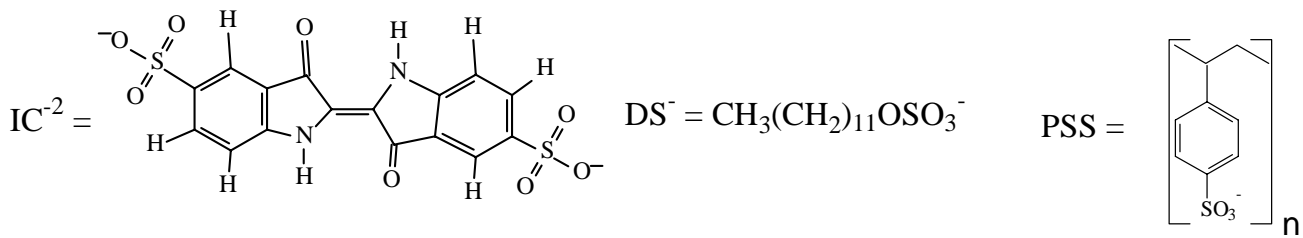

Figure 4. Electrochemical processes and color change for the devices.

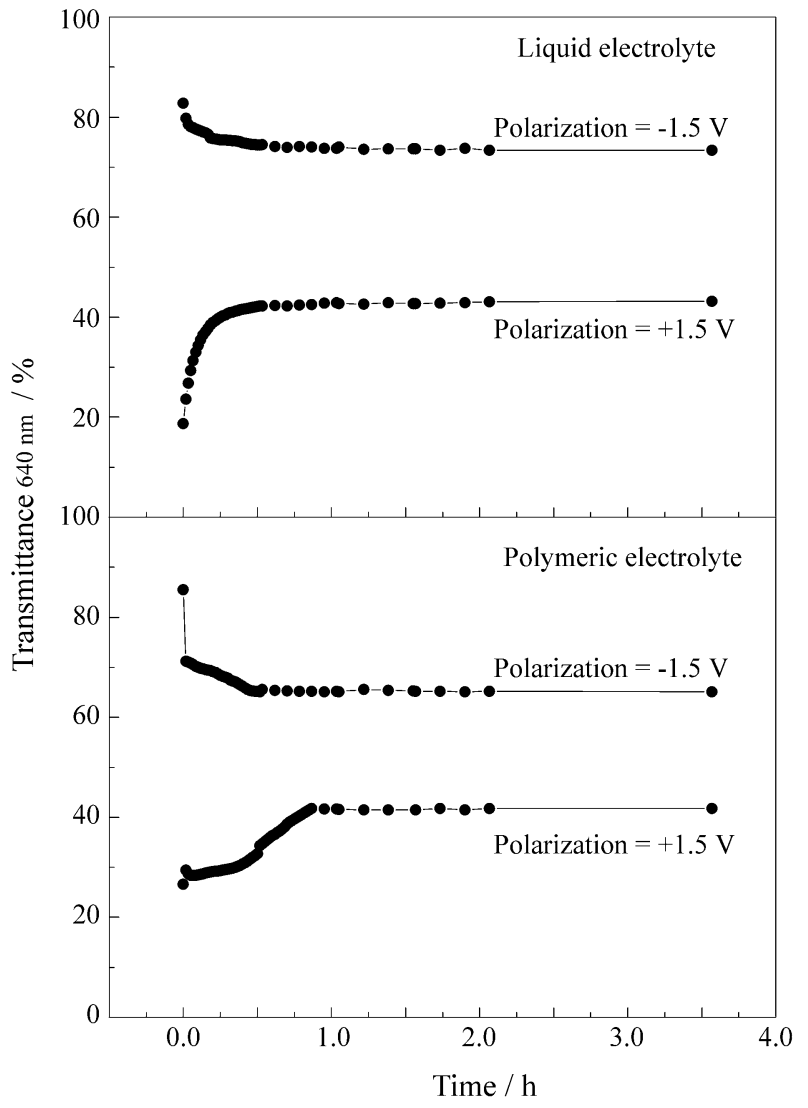

Figure 5. Optical memory: open circuit color relaxation after polarization.
Table 2 shows the $R_{e}$ values for the devices. Taking into account that the single difference between the two devices is the electrolyte layer, we observe that the values are very close and we may affirm that the conductivity of P(EPI$\mathrm{EO}) / \mathrm{LiClO}_{4}\left(\sigma=10^{-5} \mathrm{~S} \mathrm{~cm}^{-1} \text { at } 30^{\circ} \mathrm{C}\right)^{30}$ is of the same order of magnitude as the liquid electrolyte, $\mathrm{PC}-\mathrm{LiClO}_{4}$.

The calculated double layer capacitance values (CPE) are closer to the typical values obtained for interfaces than for those found for bulk characteristics ${ }^{31}$. In particular, we have four interfaces to be considered: (i) PET-ITO $\mid$ PPyDS-IC, (ii) PPy-DS-IC | electrolyte, (iii) electrolyte | PEDT-PSS and (iv) PEDT-PSS | ITO-PET. Bulk phenomena and the polymer| electrode interface should be detected at higher frequencies, thus the semicircles found in our experiments are probably due to a polymer $\mid$ electrolyte interface phenomena. Table 3 summarizes the results of the fitted parameters calculated from the impedance measurements.

At negative potentials we have the following situation: reduced PPy-DS-IC (insulating character) and oxidized PEDT-PSS (conducting character). Hence, the increase of $\mathrm{R}_{\mathrm{e}}$ in the direction $-1.5 \rightarrow 1.5 \mathrm{~V}$ indicates that PEDT-PSS reduction predominates over the system, becoming itself more resistive. At $0.0 \mathrm{~V}$ we observe two semicircles due to the PPy-DS-IC | electrolyte and electrolyte | PEDT-PSS interfaces, because of their partially conducting states. In the direction $1.5 \rightarrow-1.5 \mathrm{~V}$ we have reduced PPy-DS-IC and oxidized PEDT-PSS and the first semicircle disappears, indicating that the PEDT-PSS modified electrode has 

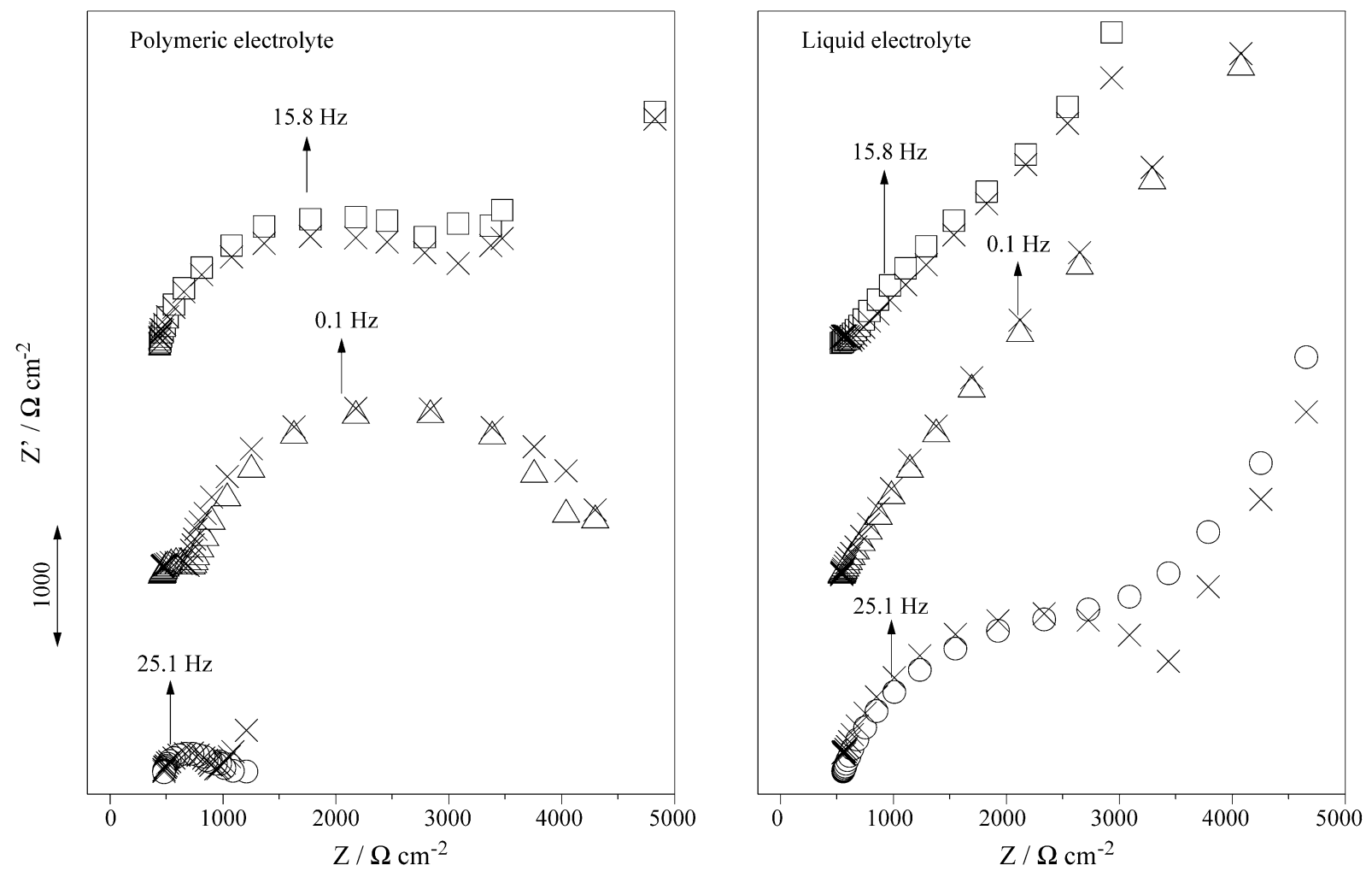

Figure 6. Nyquist plots for assembled devices using polymeric and liquid electrolytes at steady state potentials of $-1.5(\square), 0.0(\Delta)$ and $1.5 \mathrm{~V}(\mathrm{O})$. The curves were vertically shifted for easier comparison. Points marked (x) represent the data simulated with the software used.

the polymer in its full semiconductor state, showing a semi-metallic like behavior. The absence of semicircles in the liquid electrolyte device at -1.5 and $0.0 \mathrm{~V}$ indicates that, in this case, some of the considerable interfaces described above are less defined because the polymers are swollen by the electrolyte.

Table 2. Electrolyte resistance values $\left(\mathrm{R}_{\mathrm{e}} / \Omega \mathrm{cm}^{-2}\right)$ in the assembled devices with $\mathrm{PC}-\mathrm{LiClO}_{4}$ and $\mathrm{P}(\mathrm{EPI}-\mathrm{EO})-\mathrm{LiClO}_{4}$, determined from electrochemical impedance spectroscopy experiments.

\begin{tabular}{lcc}
\hline Potential / V & $\mathrm{R}_{\mathrm{e}}(\mathrm{PC})$ & $\mathrm{R}_{\mathrm{e}}(\mathrm{P}(\mathrm{EPI}-\mathrm{EO}))$ \\
\hline-1.5 & 550 & 474 \\
0.0 & 548 & 460 \\
1.5 & 583 & 430 \\
\hline
\end{tabular}

\section{Conclusions}

The electrochromic parameter, $\eta$, presented by the electrochromic devices described in this work is clearly higher than those values found in the literature, even for inorganic electrochromes ${ }^{1}$. For the liquid electrolyte device we found an exceptional value of more than $700 \mathrm{C}^{-1} \mathrm{~cm}^{2}$ while an average value of $c a .360 \mathrm{C}^{-1} \mathrm{~cm}^{2}$ was obtained for the polymer electrolyte device. In general, these values are assigned to optimal coloration efficiency with a minimum injected charge. The higher $\eta$ for the liquid electrolyte device, as well as its shorter response time, is probably due to the polymer-electrolyte contact. A liquid electrolyte could more efficiently swell the electrochrome, increasing the amount of injected electrons provided by a better ion exchange in the polymer $\mid$ electrolyte interface.

Table 3. Parameters obtained by fitting the electrochemical impedance spectroscopy data for the device with polymeric electrolyte at different polarization potentials.

\begin{tabular}{lccccccc}
\hline $\mathrm{E}[\mathrm{V}]$ & $\mathrm{R}_{\mathrm{e}}\left[\Omega \mathrm{cm}^{-2}\right]$ & $\mathrm{R}_{1}\left[\Omega \mathrm{cm}^{-2}\right]$ & $\mathrm{CPE}_{1}\left[\Omega \mathrm{s}^{-\mathrm{n} 1}\right]$ & $\mathrm{n}_{1}$ & $\mathrm{R}_{2}\left[\Omega \mathrm{cm}^{-2}\right]$ & $\mathrm{CPE}_{2}\left[\Omega \mathrm{s}^{-\mathrm{n} 2}\right]$ & $\mathrm{n}_{2}$ \\
\hline-1.5 & 430 & 3000 & $8.7 \times 10^{-6}$ & 0.82 & absent & absent & - \\
0.0 & 461 & 282 & $1.8 \times 10^{-5}$ & 0.84 & 3400 & $5.4 \times 10^{-4}$ & 0.9 \\
1.5 & 474 & 454 & $3.5 \times 10^{-5}$ & 0.79 & absent & absent & - \\
\hline
\end{tabular}


Although our devices did not present good environmental and redox stability due to the PPy-DS-IC layer, we demonstrated that these devices could be suitable for technological applications after their method of assembling and/or preparation is improved. Assembling an all-polymeric flexible electrochromic device in the form of a film opens the perspective of applying these films on already existent glass windows. This will save the costs of substituting windows and frames in existing buildings.

\section{Acknowledgments}

The authors thank FAPESP (proc. 97/02156-3) for a Ph.D. Fellowship and financial support (96/9983-0), Daiso Co. Ltd. and Bayer S.A. for P(EPI-EO) and BaytronP (PEDT-PSS) samples. We also thank Dr. W. A. Gazotti for useful comments.

\section{References}

1. Monk, P.M.S.; Mortimer, R.J.; Rosseinsky, D.R. Electrochromism: Fundamentals and Applications, VCH, New York, Ch. 2, 1995.

2. Mortimer, R.J. Chem. Soc. Rev. 1997, 26, 147.

3. Girotto, E.M.; De Paoli, M.-A. Adv. Mater. 1998, 10, 790.

4. Yano, J. J. Electrochem. Soc. 1997, 144, 477.

5. Aegerter, M.A.; Avellaneda, C.O.; Pawlicka, A.; Atik, M. J. Sol-Gel Sci. Technol. 1997, 8, 689.

6. Kubo, T.; Nishikitani, Y. J. Electrochem. Soc. 1998, 145, 1729.

7.Kulesza, P.J.; Malik, M.A.; Mieccznikowski, K.; Wolkiewics, A. J. Electrochem. Soc. 1996, 143, L10.

8. Scarminio, J.; Lourenço, A.; Gorenstein, A. Thin Solid Films 1997, 302, 66.

9. Yao, J.N.; Yang, Y.A.; Loo, B.H. J. Phys. Chem. B 1998, 102, 1856.

10.Ziemells, K. Nature 1998, 393, 619.

11.Duek, E.A.R.; De Paoli, M.-A. Mastragostino, M.; Adv. Mater. 1993, 5, 650.

12. Carpenter, M.K.; Conell, R.S. J. Electrochem. Soc. 1990, 137, 2464.
13. Arbizzani, C.; Mastragostino, M.; Meneghello, L.; Morselli, M.; Zanelli, A. J. Appl. Electrochem. 1996, 26,121 .

14. a) Mastragostino, M.; b) Scrosati, B.; c) Abraham, K.M. In Applications of Electroactive Polymers, Scrosati, B., Ed.; Chapman\&Hall, London, Ch. 7, 8, 3, 1993.

15. Kim, E.; Lee, K.-Y.; Lee, M.-H.; Shin, J.-S.; Rhee, S.B. Synth. Met. 1997, 85, 1367.

16. Michalak, F.; Aldebert. P. Solid State Ionics 1996, 85, 265.

17. De Paoli, M.-A.; Casalbore-Miceli, G.; Girotto, E.M.; Gazotti, W.A. Electrochim. Acta 1999, 44, 2983.

18. Rocco, A.M.; De Paoli, M.-A.; Zanelli, A.; Mastragostino, M. Electrochim. Acta 1996, 41, 2805.

19. Jonas, F.; Morrison, J.T. Synth. Met. 1997, 85, 1397.

20. Yamato, H.; Ohwa, M.; Wernet, W. J. Electroanal. Chem. 1995, 397, 163.

21. Yohanes, T.; Inganäs, O. Solar En. Mater. Solar Cells 1998, 51, 193.

22. Radhakrishnan, S.; Somani, P. Mat. Lett. 1998, 37, 192.

23. Bange, K.; Gambke, T. Adv. Mater. 1990, 2, 10.

24. Nijnatten, P.A.; Spee, C.I.M.A. J. Non Crystal. Sol. 1997, 218, 302.

25. Becker, H.; Witthopf, H. Proceedings of the $3^{\text {rd }}$ International Meeting on Electrochromism London, 1998, Abstract 8D.

26. Tassi, E.L.; De Paoli, M.-A. Electrochim. Acta 1994, 39, 2481.

27. Gazotti, W.A.; De Paoli, M.-A.; Casalbore-Miceli, G.; Geri, A. Adv. Mater. 1998, 10, 60.

28. De Paoli, M.-A.; Duek, E.A.R. Adv. Mater. 1992, 4, 287.

29. Boukamp, B.A.; EQUIVCRT, Version 4.51, University of Twente, The Netherlands 1995.

30. Goulart Silva, G.; Lemes, N.H.T.; Polo da Fonseca, C.N.; De Paoli, M.-A. Solid State Ionics 1997, 93, 105.

31. Johnson, B.W.; Read, D.C.; Christensen, P.; Hamnett, A.; Armstrong, R.D. J. Electroanal. Chem. 1994, 364, 103.

Received: February 18, 1999

FAPESP helped in meeting the publication costs of this article 